\title{
The Effect of Paper Compost on the Growth Rate of Peanut Plants (Arachis hypogaea L.)
}

\author{
Farida Arinie Soelistianto ${ }^{1}$, Martono Dwi Atmadja², Harrij Mukti Khristiana ${ }^{3}$ \\ Student, Doctoral Program of Environmental Science, University of Brawijaya, Malang, Indonesia ${ }^{1}$ \\ Researcher, State Polytechnic of Malang, Malang, Indonesia ${ }^{2}$ \\ Researcher, State Polytechnic of Malang, Malang, Indonesia ${ }^{3}$
}

\begin{abstract}
Paper waste is included in the Law of the Republic of Indonesia No. 18 Year 2008 on waste reduction with changes to the waste characteristics. Composting paper waste is conducted by changing the characteristics and composition of the waste that is beneficial for plants and the environment. Paper waste is a thin and flat material of the compression process of the fiber and wooden rods. Solid paper waste has organic compounds include the content of potassium $(\mathrm{K})$, calcium $(\mathrm{Ca})$, magnesium $(\mathrm{Mg})$, iron $(\mathrm{Fe})$ and sulfide, the necessary elements of the plant. Composting paper waste with Takakura method is by adding household vegetable waste and local microorganisms (MOL) from the mixture of the rice water residu with brown sugar. This research is aimed to determine the growth of peanut (Arachis hypogaea $L$.) with the application of paper compost on planting media. Paper compost utilized in this application after brooded for 7 days to prevent the occurrence of mold. The research is conducted with a laboratory scale with the composition treatment of the paper compost, sand, garden soil and dolomite limestone divided according to the treatment in a planting pot, with $\mathrm{P}_{0}$ as a control, $\mathrm{P}_{1}$ a mixture of sand and husk charcoal, and $\mathrm{P}_{2}$ the addition of dolomite limestone. The results of the observations on plant height almost the same average with 3 treatments in a pot that is $23 \mathrm{~cm}$ for 15 days, while the $\mathrm{pH}$ and temperature of the soil in the pot added lime dolomite $\left(\mathrm{P}_{2}\right)$, shows the average $\mathrm{pH}$ of 6.8 and a temperature of $24^{\circ} \mathrm{C}$. The chlorophyll content of leaves on the $30^{\text {th }}$ day after planting produces a high total leaves chlorophyll value in the control $\left(\mathrm{P}_{0}\right)$ that is $2.036(\mathrm{mg} / \mathrm{mL})$. The conclusion of this research is that the effect of paper compost can be used as organic fertilizer on the peanuts since the growth of peanut leaves show the growth pace without going chlorosis of the leaves.
\end{abstract}

Keywords: Paper waste compost, peanuts (Arachis hypogaea L.), soil pH, leaves chlorophyll

\section{INTRODUCTION}

Waste is a material that is produced from the results of human activities that may have not used again. According to the Law of the Republic of Indonesia No. 18 Year 2008 on waste management, the method of waste management with environment insight can reduce the negative impact on the environment and public health [1]. Currently, waste becomes into national issues so that the management is needed in comprehensive and integrated way. Of that 2008 Law, an activity that is systematic, thorough, and continuous is needed includes the reduction and handling of waste [2]. The type of waste that must be managed is household waste, similar to household waste, and specific litter. The utilization of various methods of management of the household waste and similar ones, has the goal to reduce garbage heaps on landfills which is increasingly difficult in the big cities. The reduction of the amount of waste by means of the garbage heaps limitation, one of which is recycling that can be utilized possibly to maximum extent. The community for the processing the amount of waste takes precedence in the natural mechanisms. The main objective of the community in waste management is by changing the characteristics, composition, and the amount of garbage and returned to the nature without becoming residues to the environment [3]. One of the types of waste that can still be recycled is paper waste. Paper is a material that is thin and flat from a compression process of the fibers from the stem wood pulp created in advance [4]. Paper demand is increasing every year so that the capacity of the pulp mill in Indonesia reached 7.9 million tons by the year 2017 increased to $26.5 \%$ which about 10 million tons. The increasing need of the pulp affect the raw material requirement of the wood which is increased by about 45 million cubic meters in 2017. In general, this increasing need of paper per year raises the negative externality against pollution and environmental damage [5]. Paper waste can be utilized as something useful based on the material of the paper that is as plant compost. Paper solid waste has organic compounds include the content of potassium $(\mathrm{K})$, calcium $(\mathrm{Ca})$, magnesium $(\mathrm{Mg})$, iron $(\mathrm{Fe})$ and sulfide as elements added in the growth of plants [6]. Type of paper that is referred to as a litter consists of multipurpose paper (HVS), kraft paper, cardboard, and plastic-coated paper [7]. Not all paper waste can be recycled, especially the food wrap paper which is coated with plastic. One of the materials that are used as elements of a paper is the cellulose in the wood fiber. Paper waste that is composted mixed with other ingredients that can simplify the decomposition of the material into a plant fertilizer. Paper is a good mix as compost because it has a high carbon content. Other ingredients that contain nitrogen 


\section{International Advanced Research Journal in Science, Engineering and Technology}

Vol. 8, Issue 6, June 2021

\section{DOI: $10.17148 /$ IARJSET.2021.8650}

are also added for making compost from paper as the rest of the household vegetables garbage, and hay. Takakura compost method is created multi-layered with some materials and doused with water and the addition of decomposer or referred to as Local Micro Organism (MOL) so that the decomposition process of the organic materials becomes faster [8]. Local micro-organisms contain macro and micronutrient elements that consist of bacteria potentially as a decomposer of organic matter, growth stimulants and as agents controlling pests and plant diseases. Compost from paper waste is used as fertilizer on the peanuts seed (Arachis hypogaea L.). Peanut is a plant that can be cultivated on different soil types [9]. Utilization of paper waste compost is possible to help the improvement of soil fertility by maintaining the soil structure containing micro and macro soil elements. Optimum soil packaging is also maintained with the addition of limestone dolomite on the growing media with mixture of paper ripe compost with land soil. Loose soil with light texture facilitates the entry of gynophore into the soil, so the roots and pods of peanuts can develop optimally [10]. The purpose of this study is to determine the effect of paper compost as organic fertilizer that is applied on peanut plants (Arachis hypogaea $L$.), as the indicator level of optimum observations on the planting media. Peanut is a plant that can easily be grown by utilizing a pot as a place of composting experiment growth of paper waste with a laboratory scale.

\section{RESEARCH METHODOLOGY}

This research is conducted in the Laboratory of the Technology Development of Plant Breeding, Faculty of Agriculture, University of Brawijaya Malang. The research is conducted in February 2021 through April 2021.

\section{A. Tools and Materials}

Equipments used in this research are Takakura plastic basket, paper cardboard, fabric mesh, black plastic as a cover, knife, plastic container, sand sieve, scissor, stationery, insulation and duct tape, ground shovels, digital scales, $\mathrm{pH}$ meters, and the plant pots with a diameter of $20 \mathrm{~cm}$ and a height of $18 \mathrm{~cm}$. The material used is selected paper waste that does not have an element of plastic, vegetable waste around $60 \%$, charcoal husk, fine sand, processed compost, land soil, a solution of the MOL from the rice water residue and a mixture of brown sugar.

\section{RESEARCH DESIGN}

Stages of the research is conducted by making the paper waste compost where papers cut into $2 \mathrm{~mm}$ pieces to make them easy decompose with other ingredients in the Takakura basket. Also adding MOL decomposer and processed compost in order to accelerate the degradation of the composting materials that brooded in the Takakura basket [11]. The compost brooded for 30 days, then every 3 days MOL added and stirred so that the ingredients mixed perfectly. After 30 days, the compost harvested and laid out in the plastic container is observed if the compost quality has a blob of material that has yet to unravel perfectly especially paper. Compost is put on the light of the sun so as not to grow the mushrooms, after it is cleared from material that allows decomposition again. The processed compost is applied to the peanuts planting media with a variation of paper compost and land soil 1:1 as the control $\left(\mathrm{P}_{0}\right)$, whereas a comparison of the quality of land soil and paper compost, fine sand is added into the pot $1\left(\mathrm{P}_{1}\right)$ with a ratio of 1:1:1, then a comparison of the level of soil acidity from a combination of the compost application is applied into pot $2\left(\mathrm{P}_{2}\right)$ with a combination of land soil, sand, paper compost, and limestone dolomite with ratio 1:1:1:1. The research variables are the $\mathrm{pH}$ levels of the soil and the soil temperature, meanwhile the physical growth of the peanut is being observed from the peanut stem height, and the content of the leaves chlorophyll on the day after planting (HST), namely day-30 [12].

A. Research Stages

Composting is conducted by making a reactor out of the Takakura basket method with the basket size $30 \times 25 \times 20 \mathrm{~cm}$ perforated on the left and right part as well as the bottom part. The inner surface of the basket coated with used cardboard neatly laid out so airtight and plastered. Used cardboard is utilized so that the material mixed inside remains moist, and reduce the insects entered during the composting process. In addition, the cardboard can also help speed up the composting process, and absorp the water from the vegetable material mixed therein. Mesh cloth sac filled with husks for pedestal and made pillow-shaped and fastened so that during the process the husk does not come out mixed with other compost material. It also used to prevent the compost leachate ooze out of the basket causing contamination to the environment. A mixture of vegetables cut into small pieces to make faster the decay, after that add the MOL as the activator so that the composting progress become faster. The final stage is putting a mixture of the processed compost and husk charcoal and covering with the husks in net cloth and plastic. Baskets are put in a place that is not exposed to direct sunlight (in shade). On the $4^{\text {th }}$ day, the MOL added to the compost then observed the changes, this is performed once every 3 days while stirred so that the compost material decayed perfectly. On the $30^{\text {th }}$ day, the compost harvested and put on the rectangle plastic container and observed the changes of color, smell and texture of the other mixed material. The compost is put under the sunrays to prevent mushrooms to grow, and before using it must be cleaned and disposed from the rest of the material that has yet fully unraveled. Prior being used as fertilizer, the compost weighed before and after the drying process. The seeds of peanuts are used for the application of compost and the test of plants physical growth.

The application of composting with a mixture of Takakura method compost that has been cleared from other material that has yet to unravel, with topsoil ground taken from land soil from the depth of $30 \mathrm{~cm}$. Land soil has the humus needed 


\section{International Advanced Research Journal in Science, Engineering and Technology}

Vol. 8, Issue 6, June 2021

\section{DOI: $10.17148 /$ IARJSET.2021.8650}

for the growth of peanuts seed. The process of measuring the soil volume is using digital scale with each pot contains soil media combined with other materials as much as 500 gram. The composition of the mixing for $\mathrm{P}_{0}$ (control) is $1: 1$ for processed paper compost and land soil; while for the combination of $\mathrm{P}_{1}$, it is 1:1:2 for the application of paper compost paper, sand, and land soil; next for the application with limestone dolomite in pot number two $\left(\mathrm{P}_{2}\right)$, the ratio is $1: 1: 1: 2$ for paper compost, sand, limestone dolomite, and land soil. Before putting everything in the pot, all ingredients are stirred with a shovel so that the material is mixed evenly. Once mixed then put into pots and placed under the sunrays before planting the peanut seeds. The peanuts soaked in a plastic container with warm water for $1 \times 12$ hour so that the peanut seed experiencing dormancy breaking where the possibility is the peanut seeds are fresh but difficult to grow perfectly. Once the seeds begin to show the radicle growing then the peanut seeds subsequently planted in a medium that had been prepared. The pot is dug to a depth of $\pm 1 \mathrm{~cm}$ which in each pot planted 6 seeds then covered with soil again and mix of materials adjusted to the treatment for daily observation. The observation is peanut stem height, $\mathrm{pH}$ and soil temperature as well as the content of leaves chlorophyll. Testing on the content of leaves chlorophyll is conducted on the peanut seeds with the condition of day after planting namely the $30^{\text {th }}$ day.

\section{RESULTS AND DISCUSSION}

The results of testing the soil media which has been applied with paper compost and dolomite to balance the nature of the soil acidic possibility of having poor nutrient, low alkaline saturation, low cation exchange capacity and a low content of organic material. Paper compost as a granulator (grain developer) of the mineral grains so that the soil has a higher level of porosity. Dolomite can lighten the soil media of paper compost application against soil acidity by observing the $\mathrm{pH}$ level of the soil media [13]. Testing is conducted by measuring the level of soil $\mathrm{pH}$ on the application of compost and soil temperature. The measurement is done every 2 days. The results of the $\mathrm{pH}$ and soil temperature test during the observation can be seen in Figure 1 for the soil $\mathrm{pH}$, and Figure 2 for soil temperature. As for the plant stem height is measured every 2 days with the results as in Figure 3.

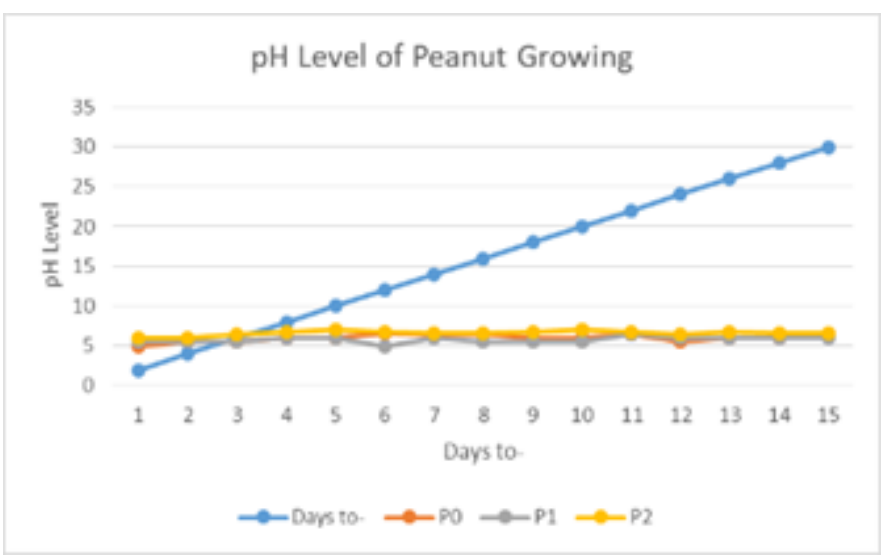

Fig.1: Chart of the Effect of Paper Compost on Soil pH

The measurement of soil acidity from the application of paper compost done every 2 days within the 30 days observation period of giving limestone dolomite to the planting media can increase the soil $\mathrm{pH}$ so the growth of the plant stem shows higher level than the media without dolomite nor the controlled one that only consists of compost and land soil.

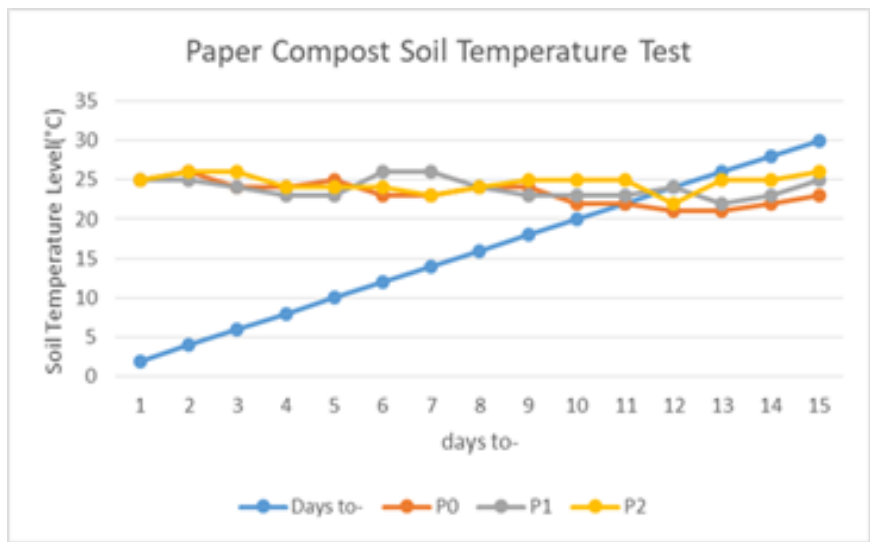

Fig.2: Chart of the Effect of Paper Compost Paper on Soil Temperature $\left({ }^{0} \mathrm{C}\right)$ 


\section{International Advanced Research Journal in Science, Engineering and Technology}

Vol. 8, Issue 6, June 2021

\section{DOI: $10.17148 /$ IARJSET.2021.8650}

The soil Media with compost application also measures the level of soil temperature, from the watering done in the morning from $07.00-08.00(\mathrm{GMT}+7)$ with half a liter of water on each watering. The balance between water, air and temperature in the soil can help the structure and the porosity of the soil. The porosity helps the development of rooting and germination of peanuts in the soil. The process of photosynthesis goes well at a temperature of about $\pm 21^{\circ} \mathrm{C}$, the temperature condition which make the formation of fast relatively glucose so that the delivery of photosynthate to all parts of the plant is increasingly high. The rate of photosynthesis is highest at the optimum temperature conditions. There is an increase of respiration above the rate of photosynthesis when the temperature rises. And when the rate of photosynthesis occurred the results of the production used more quickly. In addition, the soil temperature relates to the loss of most of the water that fills the pores of the soil so that it can go beyond the mechanism of transpiration and evaporation. Peanut plant is categorized as $\mathrm{C} 3$ plants when the initial growth occurred which requires temperature of $27^{\circ} \mathrm{C}-30^{\circ} \mathrm{C}$. This study shows that with the application of paper compost with an increase between $23^{\circ} \mathrm{C}-26^{\circ} \mathrm{C}$, the growth of the stem and leaves are optimum when utilizes the process of photosynthesis and observes the chlorophyll content of the peanut leaves.

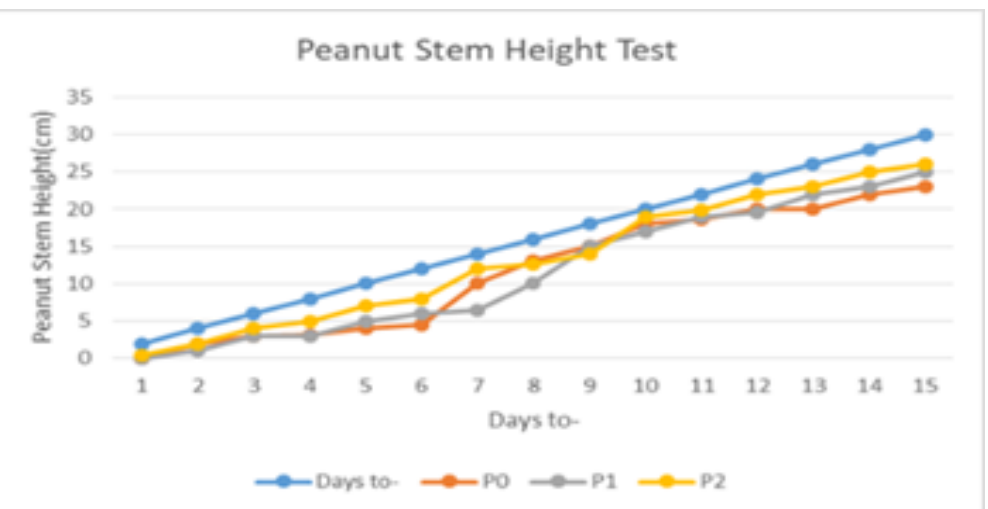

Fig.3: Chart of the Effect of Paper Compost on the Height of Peanuts Stem

The growth of height on the peanut stem is the process of division and elongation of cells that predominantly at the ends of the plants, as well as the supporting nutrients with abundant content of N, P and $\mathrm{K}$ in the soil. The application of paper compost with the addition of other elements such as dolomite, or processed compost and husk charcoal can cope with the amount of the nutrient in the soil media that is actually still insufficient for the peanut's germination. The growth of plant stem is a physiological process where cells perform the process of meiosis that specifically requires the nitrogen element. Nitrogen is the main element of protein and a portion of the chlorophyll which has an important role in the process of photosynthesis [14]. Chlorophyll is a porphyrin-magnesium attached to protein, as a catalyst for photosynthesis on the membrane of the thylakoid as the green pigment in the tissues of photosynthesized plants. These conditions are loosely bound with protein, but easy to dissolve in the extraction of the missal lipids of the ether and acetone elements. The result of photosynthesis, namely the photosynthate is used during the process of cell division so that the peanuts are becoming tall. The K element plays a role in the growth of plant height in stimulating the growth of meristematic tissues. The height of peanut stem between the 3 treatments are the same in average, but the paper compost has a grip power against the water high enough so that the plants are not easily subjected to drought [15]. The stress of drought on the soil media in physiology also affects the chlorophyll content since this parameter is closely related to the photosynthesis rate. The fundamental aspects that affect the photosynthesis rate is the mechanism of the chlorophyll biosynthesis and the formation of protochlorophyll inhibited when the potential of water is reduced. If the planting media is lacking water, then the leaf stomata cannot open thus make CO2 entry inhibited and so does the photosynthesis. The a-chlorophyll and b-chlorophyll have a strong absorption ability in the red part $(600-700 \mathrm{~nm})$, and the most least absorption of green light (500-600nm). The Table 1 presents the test data on the chlorophyll content of the peanut leaves in the $30^{\text {th }}$ day of HST.

Table 1. The Chlorophyll Content of the Peanut Leaves

\begin{tabular}{|l|l|l|l|l|}
\hline Sample & $\mathbf{a}-\mathbf{C l}(\boldsymbol{\mu g} / \mathbf{m l})$ & $\mathbf{b}-\mathbf{C l}(\boldsymbol{\mu g} / \mathbf{m l})$ & Total $\mathbf{C}(\boldsymbol{\mu g} / \mathbf{m l})$ & Total $\mathbf{C}(\mathbf{m g} / \mathbf{m l})$ \\
\hline $\mathrm{P}_{0 \text { (control) }}$ & 1542.21 & 493.54 & 2035.74 & 2.036 \\
\hline $\mathrm{P}_{1 \text { (paper compost: sand) }}$ & 1183.01 & 337.95 & 1520.96 & 1.521 \\
\hline $\mathrm{P}_{2 \text { (paper compost: dolomite) }}$ & 1479.31 & 375.25 & 1854.57 & 1.855 \\
\hline
\end{tabular}

Chlorophyll is positively correlated with the rate of photosynthesis because chlorophyll is part of the chloroplast components. From the Table 1, the effect of the application of husk charcoal, sand and paper compost on peanuts leaves chlorophyll generate data that total chlorophyll of media without husk charcoal produces a great value of leaves 


\section{International Advanced Research Journal in Science, Engineering and Technology}

Vol. 8, Issue 6, June 2021

\section{DOI: $10.17148 /$ IARJSET.2021.8650}

chlorophyll $\left(\mathrm{P}_{0}\right)$. Meanwhile the husk charcoal effects the content of water, and the presence of paper compost inhibits the rate of chlorophyll formation with the smallest data $\left(\mathrm{P}_{1}\right)$. Limestone dolomite added into the application of peanuts planting media is sufficient to help the content of leaves chlorophyll as well as the levels of soil $\mathrm{pH}$ so that the height of the peanut stem taller than others that without dolomite.

\section{CONCLUSION}

The application of paper compost on the planting media of peanuts gives the interaction between multiple material compositions of husk charcoal, sand and land soil. The result data of the soil $\mathrm{pH}$ test is according to the needs of the peanuts growth with the addition of $\mathrm{P}_{2}$ limestone dolomite by 6.8. The soil temperature affects the process of leaves photosynthesis from chlorophyll content within 30 total days after planting (HST) that is on the control $\left(\mathrm{P}_{0}\right)$ with the highest value $2.036 \mathrm{mg} / \mathrm{ml}$. The height of peanut plants measured from the stem height on the $15^{\text {th }}$ day on average is 23 $\mathrm{cm}$, the treatment of the addition of dolomite does not seemed to make much difference in the height of peanut stem. The growth rate with the application of paper compost with other materials shows the role of environment in accordance with the growth of the peanuts until the $30^{\text {th }}$ day of observation where the peanuts grow with upright stem and no chlorosis on the leaves. However, it is still necessary for a continuous research for the content of paper compost against the nutrient elements of other types of leguminous plant.

\section{REFERENCES}

[1] Hayat and Z.Hasan," a Model of Innovation Management of Household Waste", Journal of Food security, vol.2(2),pp.131-141, December 2018

[2] Mahyudin,” Waste Management Strategy Sustainability,” Journal of Enviro Scienteae, vol.10, pp. 33-40,2014

[3] M.B.Dwiyanto," Model for Increasing Community Participation And Reinforcement of Synergies In Urban Waste Management," Journal of Development Economics,vol.12(2),pp.239-256,2011

[4] R.A.Ahmad and A.K. Saftyaningsih," Utilization of Waste Paper Processing In the Production of Bags With the Technique of Paper Folding," Journal of the Level of a Bachelor's degree in Art And Design, vol. 1.(1), pp.3-6, 2011

[5] I. Sidabalok., A.Kasirang., and Suriani," the Utilization of Organic Waste Into Compost.” Journal of Science and technology Application Ngayah, vol. 5(2), pp. 85-94, 2014

[6] S.G.Adiguna., R.Pramesti., and A.B Susanto," Study on Utilization of Waste In the Processing Industry of So - so Paper Made from Raw seaweed Gracilaria sp. As a Fertilizer nicon in the top of the Plant Spinach (Amaranthus sp.)," Jurnalof Marine Research, vol.3(1), pp.37-43, 2014

[7] V.Krishna and P.A. Setiawan," Partition Board From Waste Paper," the Journal Intra, vol.5(2), pp. 802-810, 2017

[8] J.M. Widikusyanto," Make Compost With Takakura Method," http://www.researchgate.net/publication/324672801 DOI:10.13140/RG.2.226648.90885

[9] W.Dinarto and D.AStriani. “The productivity of groundnut In Dry Land At Various Intensity of Weeding,” JurnalAgriSains, vol.3(4), pp.33-43,2012

[10] N.Simanjutak.,R.Sipayung., and Mariati," Response of Growth And Production of Peanut(Arachis hypogaea L.) At a Dose of Potassium Fertilizer And Frequency Pembumbunan," Journal of Agro-technology,vol.2(4),pp.1396-1400,2014

[11] A.Rosmala.,D.Mirantika.,andW.Rabbani. "Takakura As a Solution to the Handling of Household Organic Waste," Journal Abdimas Galuh,vol.2(3),pp.165-174,2020

[12] F.Bui.,M.A..Auction.,R.I.C.O.Taolin, "the Influence of the Composition of the Growing Media And the Size of the Polybag On Growth And Yield of Tomato(Licopercicum escelentum,Mill)," journal of Conservation Agriculture in Dry Land,vol.1(1), pp.1-7,2016

[13] R.V.Arangote., B.R.De Leon Saura., C.J.R.Rollon,” Growth and Yield Response of Peanut (Arachis hypogaea L.)and Soil Charactestics with Application of Inorganic and Organic Fertilizer and Dolomite Addition," International Journal of Biosciences, vol.15(6),pp.164-173, 2019

[14] N.Rahman.,Suntoro.,and T.A.The Sakya, the"Peanut Growth And Gynophore Formation On Boron And Phosphor Applications," Journal of Soil Science and Agroclimatology, vol.16(1),pp.57-66,2019

[15] A.Taufiq.,A.Kristiono.,and D.Harnowo,"the Response of the Varieties of Ground Nuts Against Salinity Stress,"Journal of Food Crops,vol.34(2),pp.153-163,2015 